\title{
5. $\mathrm{BaSi}_{2} \mathrm{O}_{5}: \mathrm{Pb}$ 蛍光体の維持率改善
}

\author{
斉藤美保＼cjkstart稲見恒治 \\ （東芝ライテック株式会社）
}

[目的]

近年、酸化チタンの酸化力により有機物の分解を行う光触媒効果が注目され、この効果を利用した製品が実用 化され始めている。酸化チタンの光触媒反応は、 $3.0 \mathrm{eV}$ 以上、波長にして $400 \mathrm{~nm}$ 以下の光が照射されることに より生じるため、励起用光源として近紫外線に発光を有する蛍光ランプが用いられている。ところが、近紫外で 発光する蛍光体は一般的に維持率が悪いという問題点がある。このほど、近紫外に発光を有する BaS2O5 : Pb 蛍光体の維持率改善を目的として、近紫外線強度の低下要因を水銀消耗量に着目し、 $\mathrm{Y}_{2} \mathrm{O}_{3}$ で表面処理することで 維持率の向上を図ったので報告する。

[実験]

$\mathrm{Y}_{2} \mathrm{O}_{3}$ の水溶液を作成し、これに $\mathrm{BaSi}_{2} \mathrm{O}_{5}: \mathrm{Pb}$ 蛍光体を加え、 $\mathrm{p} \mathrm{H}$ を調整し沈殿させたものを乾燥させて表面 処理した。出来上がった蛍光体粉体を反射輝度により近紫外線強度を測定し、真空中にて $185 \mathrm{~nm}$ 柴外光を照射 して劣化率を調べた。

また、表面処理した蛍光体と無処理の蛍光体をそれぞれ塗布した蛍光ランプ（FL15BL）を作成し、寿命試験 を行った。さらに、試験途中で蛍光体とガラスの水銀消耗量を測定した。 [結果]

表. 1 に表面処理した蛍光体と無処理の蛍光体粉体の劣化率を示 した。

表.1 粉体における $185 \mathrm{~nm}$ 劣化率

\begin{tabular}{|c|c|c|}
\hline & 無処理 & 表面処理 \\
\hline 粉体輝度比 $(\%)$ & 100 & 100 \\
\hline $185 \mathrm{~nm} \times 4$ 時間照射後の劣化率 & 86.4 & 86.1 \\
\hline
\end{tabular}

表面処理した蛍光体の紛体輝度は、無処理蛍光体と同等であり、185 $\mathrm{nm}$ による劣化率もほぼ同等である事から $\mathrm{Y}_{2} \mathrm{O}_{3}$ によって 185 および 254 $\mathrm{nm}$ が吸収されていないと考えられる。また、185nm 紫外線を 4 時間照 射した後の紛体輝度の劣化率も同等であった。

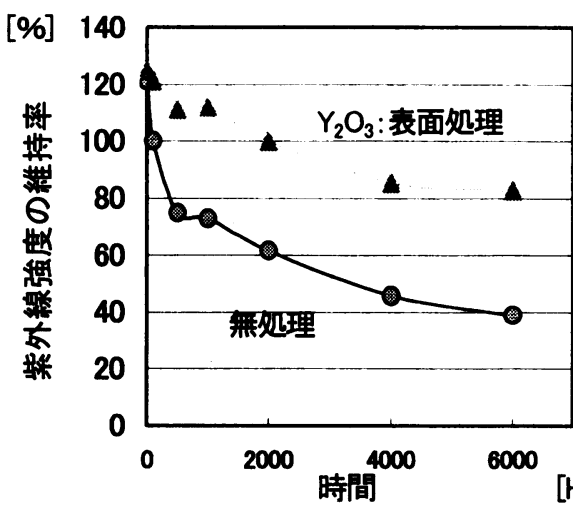

図 1 にランプの維持率を示した。表面処理することによって、6000 時間 で約 $20 \%$ の維持率改善が見られ、特に初期（100 1000 時間）の改善が 著しくなっている。

図 2 に各時間における蛍光体の水銀消耗量を示した。500 時間では無処理 に比べて、表面処理したものは水銀消耗量が約 $1 / 10$ に減少し、その後も表 面処理した方が傾きが小さく、水銀を消耗していない。ガラスで消費され る水銀量は両者とも同等である事から、 $\mathrm{BaSi}_{2} \mathrm{O}_{5}: \mathrm{Pb}$ 蛍光体の維持率低下 の主要因は水銀の吸着であると考えられる。

[結論]

$\mathrm{BaSi}_{2} \mathrm{O}_{5}: \mathrm{Pb}$ 蛍光体を用いた蛍光ランプでは近紫外線強度の低下要因は 主に水銀消耗によるものであり、特に点灯初期の吸着が大きい。このため、 $\mathrm{Y}_{2} \mathrm{O}_{3}$ で表面処理すると水銀消耗量が減少し、近紫外線強度の維持率が改善

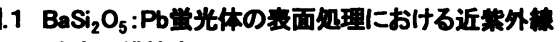
运度の灌持專

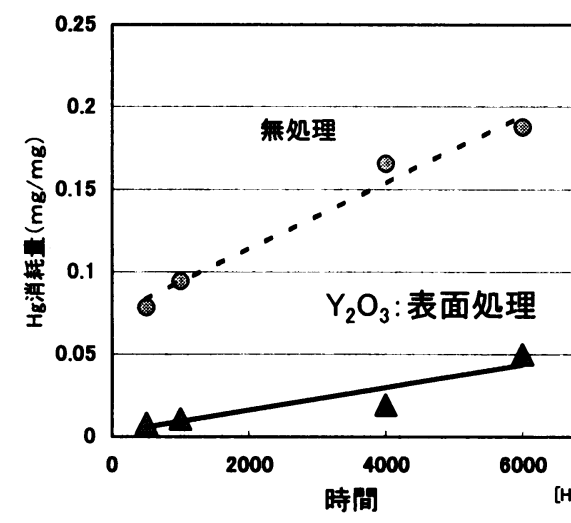

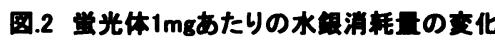
されると考えられる。

[謝辞]

蛍光体および表面処理の提供にあたり、（株）東芝デイスプレー部品材料社の諸氏に深謝致します。 [参考文献]C.R.Ronda, International Display Workshop 95, 69 Improvement of intensity maintenance of fluorescent lamp with $\mathrm{BaSi}_{2} \mathrm{O}_{5}: \mathrm{Pb}$ near ultraviolet phospher Miho Saito, Inami koji 